\title{
Seasonality in Mutual Fund Flows
}

\author{
Hyung-Suk Choi, Ewha Womans University, Korea
}

\begin{abstract}
In this paper the author established the presence of seasonality in cash flows to U.S. domestic mutual funds. January is the month with the highest net cash flows to equity funds and December is the month with the lowest net cash flows. The large net flows in January are attributed to increased purchases, and the small net flows in December are due to increased redemptions. Thus, the turn-of-the-year period is the time that most mutual fund investors make their investment decisions.
\end{abstract}

Keywords: Mutual fund flows, Seasonality test, Turn-of-the-year effect, Tax treatment, Performance of mutual funds

\section{INTRODUCTION}

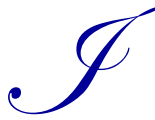

nvestor demand for mutual funds has increased substantially over the years. At the end of 2007, the U.S. mutual fund industry had $\$ 12$ trillion in assets under management, and the net cash inflow to mutual funds had increased from $\$ 112$ billion in 1991, to $\$ 883$ billion in 2007 . Consequently, extensive academic research has examined various aspects of the mutual fund industry. In particular, many studies examine cash flows entering and exiting mutual funds to gain a deeper understanding of the behavior of mutual fund investors (see Ippolito (1992), Gruber (1996), Sirri and Tufano (1998), Zheng (1999), Frazzini and Lamont (2008), and Johnson and Poterba (2010)).

A voluminous literature has shown that there is a strong seasonal component to investors' trading behavior. ${ }^{1}$ However, much less attention has been devoted to the seasonal regularity in the behavior of mutual fund investors. Mutual fund investors' behavior could be somewhat different from that of individual investors in the stock market, as they have different holding periods and face different fee structures, transaction costs, and tax treatment on distributions. This paper analyzes the seasonality in mutual fund investors' trading behavior by studying the seasonality in cash flows to mutual funds.

Recently, Johnson and Poterba (2010) examine the impact of taxes on the timing of mutual fund purchases. They find that some investors time the purchases of mutual fund shares to avoid the tax acceleration associated with distributions. Additionally, Bergstresser and Poterba (2002) explore the relationship between after-tax returns that taxable investors earn on equity mutual funds and the subsequent cash inflows to these funds. Considering that most equity mutual funds pay dividends in December, the inclination of investors to time their purchases could cause the net cash flows to equity funds to be high in January and low in December. Indeed, the Investment Company Fact Book reports that net cash flows to equity mutual funds were $\$ 28.3$ billion in January 2007 , but only $\$ 1.3$ billion in December 2007.

Abel, Eberly, and Panageas (2007) show that even a small observation cost can induce investors to review and adjust their holdings intermittently. ${ }^{2}$ Jagannathan and Wang (2007) find that the consumption-based asset pricing model (CCAPM) performs better if the consumption growth is measured based on the fourth quarter rather than other quarters. Therefore, they suggest that all investors are likely to make their consumption and investment decisions simultaneously during the fourth quarter. Given that December is the end of the fiscal year of most firms

\footnotetext{
${ }^{1}$ See, for instance, Chakravarty (2001), Ng and Wang (2004), Carhart, Kaniel, Musto, and Reed (2002), Hirshleifer and Shumway (2003), Bouman and Jacobsen (2002), and Hong and Yu (2009).

${ }^{2}$ In their calculation, even a small observation of one basis point of wealth implies eight months of decision interval.
} 
and the tax year of individual investors, investors are induced to review their holdings and make asset allocation decisions around the turn-of-the-year. For mutual fund investors, the turn-of-the-quarter period would also be the time to review holdings and make asset allocation decisions. This is because mutual funds must report their past performance up to the last calendar quarter end, as required by the advertising guidelines proposed by the National Association of Securities Dealers (NASD). Chahart, Kaniel, Musto and Reed (2002) present evidence that funds with the best performance mark up to improve their year-end ranking and to profit from the convexity of their flow performance relation.

Mutual fund flows are commonly used by practitioners as a measure of investor sentiment. Considering mutual fund investors as the least informed investors in the market (because they delegate their portfolio management to fund managers), mutual fund flows would reflect investor sentiment. Warther (1995) and Edelen and Warner (2001) report a positive relationship between fund flows and subsequent returns. By examining the direct measure of investor sentiment, Indro (2004) finds that fund flows are higher when individual investors become more bullish. Recently, Kamstra, Kramer, Levi, and Wermers (2010) argue that the investor's risk aversion would vary across different seasons, resulting in seasonal patterns in fund flows. Seasonal patterns in fund flows may not have a substantial influence on the empirical studies if annual fund flows are examined. Any research with monthly cash flows to mutual funds, however, must consider seasonal patterns in fund flows, especially when the patterns are not simply reflecting the patterns in stock returns. This has been thoroughly studied in previous literature. ${ }^{3}$ Fant (1999) includes the 12th lag of the fund flows in the VAR model to control seasonal effects. In his study, after controlling for seasonal effects, he finds no relation between returns and lagged fund flows.

In this paper, the author establishes the presence of seasonality in U.S. domestic equity mutual fund flows using the combined databases of the CRSP and N-SAR filings. The author finds that equity funds receive the highest net cash flows in January and the lowest in December. The large net flows in January are attributed to increased purchases, and the small net flows in December are due to increased redemptions. Thus, the turn-of-the-year is the time that most mutual fund investors make their investment decisions. Unlike the turn-of-the-year period, the author does not find any abnormal increase or decrease in fund flows around the turn-of-the-quarter.

The rest of this paper is organized as follows. Section 2 describes the sample and provides preliminary analysis. Section 3 reports the empirical results of the seasonality test of the cash flows to the U.S. domestic mutual funds. 4. In Section 4, the turn-of-the-year effect and the turn-of-the-quarter effect in mutual fund flows are rigorously examined. Finally, Section 5 concludes.

\section{CASH FLOWS TO MUTUAL FUNDS}

\section{Data}

This study examines seasonal patterns in net flows, inflow, and outflow to U.S. domestic equity mutual funds over the fourteen-year period beginning in January 1994 through December 2007. The sample is based on the mutual fund database compiled by Center for Research in Security Prices Survivor Bias Free Mutual Fund Data base (hereafter referred to as CRSP database) and mutual funds' N-SAR filings with the U.S. Securities and Exchange Commission (SEC).

The CRSP database provides fund share class level information on monthly total net assets (TNA), monthly returns, asset classes (equity vs. bond fund), style objectives, and names for all open-end mutual funds. The author included 15,283 U.S. domestic equity fund classes from January 1994 to December 2007 in this study. ${ }^{4}$ To avoid possible upward bias in the reported returns of the smallest funds, the author eliminated funds with less than $\$ 15$ million in assets under management following previous literature. (See, Elton, Gruber, and Blake (2001) and Chen, Hong, Huang, and Kubik (2004)). In doing so, the author has 9,278 equity fund classes reported in the CRSP database.

\footnotetext{
${ }^{3}$ See, for example, Rozeff and Kinney (1976), Keim (1983), Reinganum (1983), Roll (1983), Lakonishok and Smidt (1988), Ariel (1987), Ritter and Chopra (1989), Agrawal and Tandon (1994), French (1980), and Lakonishok and Maberly (1990)

${ }^{4}$ I exclude the international funds, natural resources funds, and index funds.
} 
All mutual funds are required to file N-SARs with the SEC every six months based on their fiscal year. NSAR filings contain information on the dollar amount of new sales, reinvestment of dividends and distributions, other sales, and redemptions for each month covered by the filing. N-SAR filings also identify the total net assets of mutual funds at the end of the period that is covered by the filing. Due to data availability, the author collected all N-SARs pertaining to calendar years 1994 through 2007 from the SEC's Edgar website. ${ }^{5}$ The author then matched a fund's N-SAR filing with the CRSP database based on the fund and family names.

N-SARs report the monthly dollar flows in and out of mutual funds at the fund level, however the CRSP mutual fund database treats fund share classes as different entities. Therefore, the author manually identified the share classes of a fund according to fund names and calculates total net asset values and monthly fund returns at the fund level to match them to the N-SAR filings. As a result, the author obtained matched mutual fund level data containing 3,346 domestic equity funds over the period from January 1994 to December 2007. Out of 9,278 fund classes, the matched sample consists of 6,322 fund classes between the CRSP database and the N-SAR filings with the SEC. On average, the matched funds manage greater assets than the unmatched funds but they generate lower returns and make lower distributions. The median of each statistic, however, shows that the matched and unmatched funds have similar characteristics.

Net flows, inflows, and outflows

By using the combined database from the CRSP and N-SAR filings, the author is able to identify monthly cash inflows and outflows to mutual funds separately. Inflow is defined as

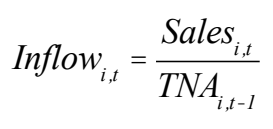

where Sales ${ }_{i, t}$ is the amount of new money invested into a fund over a month. Outflow is defined as

$$
\text { Outflow }_{i, t}=\frac{\text { Redemptions }_{i, t}}{T_{N A_{i, t} I}}
$$

where Redemptions $\mathrm{i}_{\mathrm{i}, \mathrm{t}}$ is the amount of money withdrawn from a fund over a month. The author also defines the net flows for a matched fund, Net Flows, as

$$
\text { Net Flows }_{i, t}=\text { Inflow }_{i, t} \quad \text { Outflow }_{i, t}
$$

The author eliminated from the sample those observations that appear to have data entry errors. Specifically, the author excluded observations with Net Flows, Inflow, or Outflow that is less than -90 percent or greater than 100 percent, leaving me with a final sample of 186,229 equity fund-month observations.

The author then plotted the mean of the value weighted average inflow, outflow, and net flows to equity funds by month in Figure 1. There is a downward trend in both inflow and outflow to equity funds but the slope of the trend in outflow is much weaker than that of the trend in inflow. The seasonal patterns in the net flows to funds could be affected more by the seasonal patterns in inflow than that of outflow. However, the author noted that inflow and outflow tend to move together. For instance, January is the month when both inflow and outflow to equity funds are at the highest. Later on, both inflow and outflow rebound in March, but they are low in September. It is interesting that December is neither the month with the lowest inflow nor the month with the highest outflow, whereas December is the month with the lowest net flows. Thus, to understand the seasonal patterns in net flows, it is necessary to study the patterns in both inflow and outflow to equity funds.

\footnotetext{
${ }^{5}$ http://www.sec.gov/edgar.shtml
} 


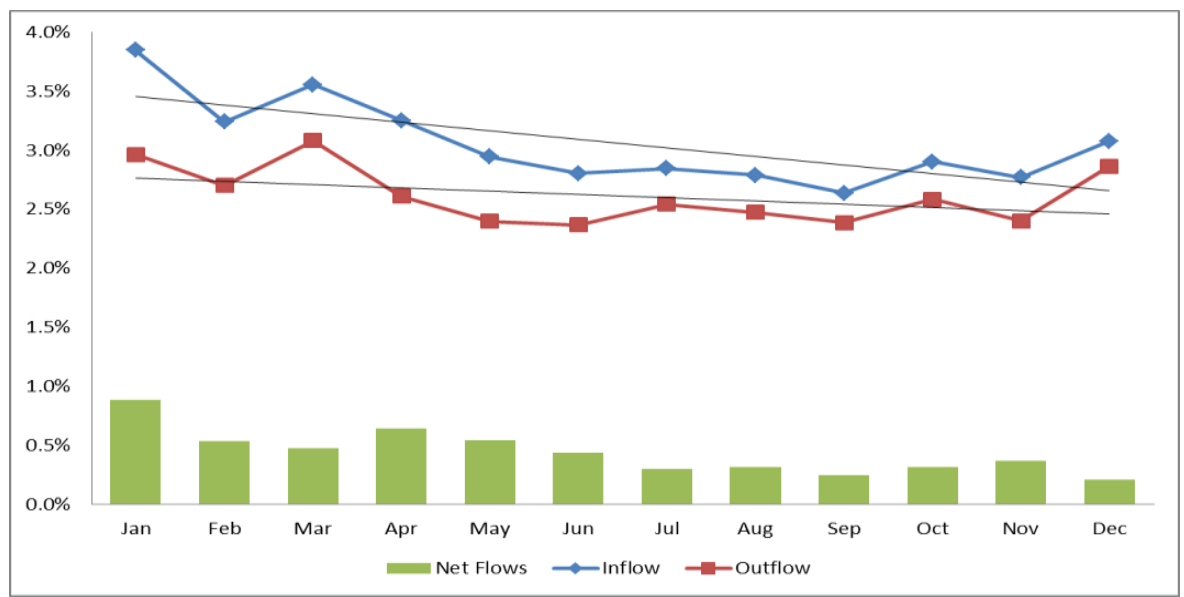

Figure 1: Inflow, Outflow, And Net Flows To Equity Funds By Month

\section{SEASONAL PATTERNS IN CASH FLOWS TO MUTUAL FUNDS}

The most intriguing findings on the seasonal patterns in cash flows to equity funds are that the highest net flows are in January and the lowest net flows are in December. In addition, the net flows rebound in April, August, and October as the author observed in Figure 1. To examine whether the relatively low net flows in December are related to the distribution schedule, the author reported the mean of the value weighted average inflow, outflow, and net flows to equity funds by month, and the mean of the value weighted capital distribution ratio (Capital Distribution), and income distribution ratio (Income Distribution), by month in Table 1. The author calculated Capital Distribution (Income Distribution) as the amount of capital gain (income dividend) distribution per share, divided by the reinvestment price. The results reported in Table 1 show that income distributions are made mostly at the end of each quarter and most of the capital distributions are made in December. It appears that mutual funds investors do not put additional cash to their mutual fund account in a month with large distribution.

Table 1: Mutual Fund Flows, Distributions, And Performance By Month

\begin{tabular}{lccccccccccccc}
\hline & Jan & Feb & Mar & Apr & May & June & July & Aug & Sept & Oct & Nov & Dec & Avg. \\
\hline Inflow & 3.84 & 3.24 & 3.55 & 3.25 & 2.94 & 2.80 & 2.84 & 2.79 & 2.63 & 2.90 & 2.77 & 3.07 & 3.05 \\
\hline Outflow & 2.96 & 2.70 & 3.08 & 2.61 & 2.39 & 2.36 & 2.54 & 2.47 & 2.39 & 2.58 & 2.40 & 2.86 & 2.61 \\
\hline Net Flow & 0.88 & 0.54 & 0.47 & 0.64 & 0.55 & 0.44 & 0.30 & 0.31 & 0.25 & 0.32 & 0.37 & 0.21 & 0.44 \\
\hline $\begin{array}{l}\text { Capital } \\
\text { Distribution }\end{array}$ & 0.02 & 0.02 & 0.07 & 0.02 & 0.15 & 0.08 & 0.04 & 0.05 & 0.19 & 0.11 & 0.35 & 3.79 & 0.41 \\
\hline $\begin{array}{l}\text { Income } \\
\text { Distribution }\end{array}$ & 0.01 & 0.02 & 0.16 & 0.02 & 0.03 & 0.21 & 0.03 & 0.02 & 0.17 & 0.04 & 0.02 & 0.59 & 0.11 \\
\hline $\begin{array}{l}\text { Fund } \\
\text { Performance }\end{array}$ & 0.98 & -0.03 & 0.48 & 1.49 & 1.05 & 0.78 & -0.61 & -0.19 & -0.02 & 1.85 & 0.91 & 1.83 & 0.79 \\
\hline $\begin{array}{l}\text { Stock Market } \\
\text { Performance }\end{array}$ & 0.60 & -0.12 & -0.27 & 0.16 & 0.37 & 0.03 & -0.05 & 0.29 & -0.35 & 0.58 & -0.45 & -0.39 & -0.01 \\
\hline
\end{tabular}

Seasonal patterns in stock market returns, such as the January effect, have been well examined in previous literature. (See, Keim (1983), Roll (1983), Ariel (1987), Musto (1997), Ritter (1988), and Haugen and Lakonishok (1988)) If investors decide to buy or sell mutual funds, following stock market performance, the seasonal patterns in cash flows to mutual funds are simply a reflection of the seasonal patterns in stock market returns. In addition, many studies have documented the relationship between the cash flows to mutual funds and fund performance. (See, Ippolito (1992), Hendricks, Pael, and Zeckbauser (1994), Warther (1995), Gruber (1996), Chevalier and Ellison (1997), and Sirri and Tufano (1998)) To see whether the seasonal patterns in flows are strongly related with the seasonal patterns in fund performance and stock market performance, the author reported the value weighted 
average monthly returns ${ }^{6}$ on the mutual funds in the sample and the average monthly returns on the S\&P 500 index over the sample period by month in Table 1 .

Mutual funds seem to perform better in the first month of the first and second quarter. In January, the average monthly return of mutual funds is 0.98 and in April is 1.49, which is much higher than the average return in other months of the quarter. January and April are the months with the highest fund flows in the first and second quarter. However, mutual funds perform much better throughout the fourth quarter than in the previous three quarters of the year, while net cash flows to mutual funds are relatively low in these three months.

Regarding stock market performance, the seasonal patterns in fund flows would be related with the seasonal patterns in the returns on stock markets if mutual fund investors consider stock market conditions when they decide to buy or sell. The stock market seems to perform better in the first month of each quarter than in the other months over the sample period. The magnitude of fund flows in January is much higher than the other months, whilst the return on the S\&P 500 index in January is similar to the return in October. The seasonal patterns in fund performance and stock market performance seem to be related with the seasonal patterns in fund flows. Whether or not there is a monthly pattern in flows, even after correcting for returns, will be thoroughly examined in the later sections.

As January has the highest net flows, and the net flows in April and October are higher than those in the prior months, investors appear to rebalance asset allocation more actively at the turn of the year and the turn of the quarter than the rest of the year. Thus, the author statistically tested whether seasonal patterns exist in cash flows to equity mutual funds by examining the influence of the calendar month of the year to the fund flows after controlling the factors influencing the fund flows such as fund performance and stock market performance. In Table 2, the author presented the results from the initial year fixed effects regression with the 11 calendar month dummy

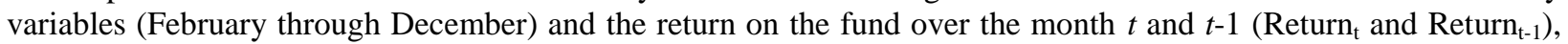
and also the S\&P500 return over the month $t$ and $t-1\left(\mathrm{~S} \& \mathrm{P} 500_{\mathrm{t}}\right.$ and $\left.\mathrm{S} \& \mathrm{P} 500_{\mathrm{t}-1}\right)$. The author ran this regression on the monthly Inflow, Outflow, and Net Flows to the U.S. domestic equity funds in the matched sample as defined in equations (1)-(3). The expected flows to mutual funds in January are measured by the intercept, while the coefficients for the 11 calendar month dummy variables represent the difference between the expected flows in January and other calendar months after controlling for fund performance and stock market performance.

Table 2 shows the estimation results on the inflow, outflow, and net flows to equity funds in the matched sample and on the net flows to equity funds reported in the CRSP database. The intercepts are significantly positive in all models when the author used different cash flow measures as the dependent variable. The inflows to mutual funds are significantly higher in January than the other months of the year. Although the outflows in January are higher than the outflows in most of the calendar months, they are significantly higher in December than in January. In January the net flows to equity funds are higher than those in the other months of the year. The high net flows are driven by the increased inflow. In fact, the outflow is higher, not lower, in January. One of the possible reasons for the high outflow in January could be investors moving from one fund to another. Also, investors can open the retirement accounts until April 15th for designating the previous year for the contribution, which could make the overall inflows in the first quarter abnormally large. That is, mutual fund investors may rebalance their portfolios in January more actively than they do during the rest of the year.

After controlling for fund performance and stock market performance, the inflows to equity funds in December do not seem to be different from the other months, however the outflow increases significantly at the five percent level. This results in lower net flows in December, which suggests that current investors tend to sell their shares more in December. After controlling for seasonal patterns, the net cash flows to mutual funds follow the fund performance. That is, the coefficients for both the current and previous month's fund performance are significantly positive. In fact, for the fund with higher returns, the sales increase and the redemptions decrease.

\footnotetext{
${ }^{6}$ The relative superior performance of our sample funds to S\&P 500 is due to the better performance of large funds over the sample periods as the performance is measured by the value weighted average monthly return.
} 
Table 2: Seasonality Of Cash Flows To Mutual Funds

\begin{tabular}{|c|c|c|c|}
\hline & Inflows & Outflows & Net Flows \\
\hline \multirow{2}{*}{ Intercept } & $4.540 * * *$ & $3.806 * * *$ & $0.733 * * *$ \\
\hline & $(45.65)$ & $(42.61)$ & $(9.00)$ \\
\hline \multirow[b]{2}{*}{ Feb } & $-0.655 * * *$ & $-0.415^{* *}$ & $-0.239 * * *$ \\
\hline & $(-6.14)$ & $(-4.34)$ & $(-2.74)$ \\
\hline \multirow{2}{*}{ March } & $-0.267^{*} *$ & 0.017 & $-0.285 * * *$ \\
\hline & $(-2.56)$ & $(0.18)$ & $(-3.33)$ \\
\hline \multirow[b]{2}{*}{ Apr } & $-0.656 * * *$ & $-0.335 * * *$ & -0.321 \\
\hline & $(-6.36)$ & $(-3.61)$ & $(-3.80)$ \\
\hline \multirow{2}{*}{ May } & $-0.968 * * *$ & $-0.522 * * *$ & $-0.446 * * *$ \\
\hline & $(-9.42)$ & $(-5.65)$ & $(-5.30)$ \\
\hline \multirow{2}{*}{ June } & $-1.079 * * *$ & $-0.559 * * *$ & $-0.521 * * *$ \\
\hline & $(-10.36)$ & $(-5.97)$ & $(-6.11)$ \\
\hline \multirow{2}{*}{ July } & $-0.845 * * *$ & $-0.466^{* *}$ & $-0.377 * * *$ \\
\hline & $(-8.14)$ & $(-5.01)$ & $(-4.45)$ \\
\hline \multirow[b]{2}{*}{ Aug } & $-0.899 * * *$ & $-0.629 * * *$ & $-0.270 * * *$ \\
\hline & $(-8.66)$ & $(-6.75)$ & $(-3.17)$ \\
\hline \multirow[b]{2}{*}{ Sept } & $-1.185 * * *$ & $-0.654 * * *$ & $-0.531 * * *$ \\
\hline & $(-11.38)$ & $(-6.99)$ & $(6.23)$ \\
\hline \multirow{2}{*}{ Oct } & $-0.794 * * *$ & $-0.425 * * *$ & $-0.370 * * *$ \\
\hline & $(-7.80)$ & $(-4.64)$ & $(-4.44)$ \\
\hline \multirow{2}{*}{ Nov } & $-1.292 * * *$ & $-0.588 * * *$ & $0.703 * *$ \\
\hline & $(-11.97)$ & $(-6.07)$ & $(-7.96)$ \\
\hline \multirow{2}{*}{ Dec } & $-0.363 * * *$ & $0.209 * *$ & $-0.845 * * *$ \\
\hline & $(-6.11)$ & $(2.33)$ & $(-9.91)$ \\
\hline \multirow{2}{*}{ Return $_{t}$} & $0.104 * * *$ & -0.026 & $0.130 * * *$ \\
\hline & $(25.22)$ & $(-7.14)$ & $(38.63)$ \\
\hline \multirow{2}{*}{$\operatorname{Return}_{\mathrm{t}-1}$} & $0.085^{* * *}$ & -0.005 & $0.090 * * *$ \\
\hline & $(21.11)$ & $(-1.27)$ & $(27.17)$ \\
\hline \multirow{2}{*}{ S\&P500 } & $-0.112 * * *$ & 0.005 & $-0.117 * * *$ \\
\hline & $(-4.84)$ & $(0.22)$ & $(-6.15)$ \\
\hline \multirow{2}{*}{$\mathrm{S \& P500}{ }_{\mathrm{t}-1}$} & -0.018 & $-0.076 * * *$ & $0.058 * * *$ \\
\hline & $(-0.78)$ & $(-3.65)$ & $(3.05)$ \\
\hline Year fixed effect & Yes & Yes & Yes \\
\hline $\mathbf{N}$ & 185,918 & 185,918 & 185,918 \\
\hline $\mathbf{R}^{2}$ & 0.013 & 0.004 & 0.015 \\
\hline
\end{tabular}

Note: $* * *, * *$, and $*$ denote the significance level at $1 \%, 5 \%$, and $10 \%$, respectively 
Table 3: Seasonality of Cash Flows to Fund Families

\begin{tabular}{|c|c|c|c|}
\hline & Inflows & Outflows & Net Flows \\
\hline Intercept & $\begin{array}{c}3.526 * * * \\
(22.59)\end{array}$ & $\begin{array}{c}3.122 * * * \\
(23.07)\end{array}$ & $\begin{array}{c}0.404 * * * \\
(3.30)\end{array}$ \\
\hline Feb & $\begin{array}{c}-0.725^{* * * *} \\
(-4.49)\end{array}$ & $\begin{array}{c}-0.438 * * * \\
(-3.13)\end{array}$ & $\begin{array}{c}-0.287 * * \\
(-2.27)\end{array}$ \\
\hline March & $\begin{array}{c}-0.269 * * \\
(-1.70)\end{array}$ & $\begin{array}{c}-0.103 \\
(-0.75) \\
\end{array}$ & $\begin{array}{l}-0.167 \\
(-1.34) \\
\end{array}$ \\
\hline Apr & $\begin{array}{c}-0.722 * * * \\
(-4.62)\end{array}$ & $\begin{array}{c}-0.433 * * * \\
(-3.28) \\
\end{array}$ & $\begin{array}{c}-0.278 * * \\
(-2.27) \\
\end{array}$ \\
\hline May & $\begin{array}{c}-0.900 * * * \\
(-5.77)\end{array}$ & $\begin{array}{c}-0.599 * * * \\
(-4.43)\end{array}$ & $\begin{array}{c}-0.301 * * \\
(-2.46)\end{array}$ \\
\hline June & $\begin{array}{c}1.021 * * * \\
(-6.41)\end{array}$ & $\begin{array}{l}-0.587 \\
(-4.28)\end{array}$ & $\begin{array}{c}-0.426^{* *} \\
(-3.43)\end{array}$ \\
\hline July & $\begin{array}{c}-1.135^{* * * *} \\
(-7.23)\end{array}$ & $\begin{array}{c}-0.611 * * * \\
(-4.49)\end{array}$ & $\begin{array}{c}-0.524 * * * \\
(-4.25)\end{array}$ \\
\hline Aug & $\begin{array}{c}-1.052 * * * \\
(-6.68)\end{array}$ & $\begin{array}{l}-0.534 \\
(-3.91)\end{array}$ & $\begin{array}{c}-0.518 * * * \\
(4.19)\end{array}$ \\
\hline Sept & $\begin{array}{c}-1.276^{* *} \\
(-8.07)\end{array}$ & $\begin{array}{c}-0.673 * * * \\
(-4.91)\end{array}$ & $\begin{array}{c}-0.603 * * * \\
(-4386)\end{array}$ \\
\hline Oct & $\begin{array}{c}-0.968 * * * \\
(-6.28)\end{array}$ & $\begin{array}{c}-0.569 * * * \\
(-4.26) \\
\end{array}$ & $\begin{array}{c}-0.399 * * * \\
(-3.30) \\
\end{array}$ \\
\hline Nov & $\begin{array}{c}-1.077 * * * \\
(-6.59)\end{array}$ & $\begin{array}{c}-0.707 * * * \\
(-4.99)\end{array}$ & $\begin{array}{c}-0.370 * * * \\
(-2.88)\end{array}$ \\
\hline Dec & $\begin{array}{c}-0.540 * * * \\
(-3.42)\end{array}$ & $\begin{array}{l}00183 \\
(1.34)\end{array}$ & $\begin{array}{c}-0.723 * * \\
(-5.83)\end{array}$ \\
\hline $\mathrm{S \& P500}_{\mathrm{t}}$ & $\begin{array}{l}-0.019 \\
(-0.56)\end{array}$ & $\begin{array}{c}-0.052^{*} \\
(-1.75)\end{array}$ & $\begin{array}{c}0.32 \\
(1.21)\end{array}$ \\
\hline$S \& P 500_{t-1}$ & $\begin{array}{l}0.001 \\
(0.02) \\
\end{array}$ & $\begin{array}{l}-0.044 \\
(-1.48) \\
\end{array}$ & $\begin{array}{c}0.045^{*} \\
(1.67) \\
\end{array}$ \\
\hline $\begin{array}{l}\text { Year fixed effect } \\
\mathbf{N} \\
\mathbf{R}^{2}\end{array}$ & $\begin{array}{c}\text { Yes } \\
46,876 \\
0.013\end{array}$ & $\begin{array}{c}\text { Yes } \\
46,876 \\
0.010\end{array}$ & $\begin{array}{c}\text { Yes } \\
46.876 \\
0.008\end{array}$ \\
\hline
\end{tabular}

Note: $* * *, * *$, and $*$ denote the significance level at $1 \%, 5 \%$, and $10 \%$, respectively

After controlling for fund performance and stock market performance, the inflows to equity funds in December do not seem to be different from the other months, however the outflow increases significantly at the five percent level. This results in lower net flows in December, which suggests that current investors tend to sell their shares more in December. After controlling for seasonal patterns, the net cash flows to mutual funds follow the fund performance. That is, the coefficients for both the current and previous month's fund performance are significantly positive. In fact, for the fund with higher returns, the sales increase and the redemptions decrease.

If all funds in a family report quarter-end results at the same period then there could appear to be monthly patterns in the cash flows to those funds. To examine this fund family effect, the author ran the regression on the value weighted average cash flows to U.S. domestic equity fund families. The author grouped funds into families based on the management company abbreviation from the CRSP database. Table 3 shows the estimation results on the inflow, outflow, and net flows to equity fund families. The intercepts are significantly positive in all models when the author used different cash flow measures as the dependent variable. The inflows to mutual fund families are significantly higher in January than the other month of the year. The outflows in January are higher than the outflows in most of the calendar months but they are not significantly higher than the outflows in March or December. In January the net flows to equity fund families are higher than those in the other months of the year. The high net flows are driven by the increased inflow. In fact, the outflow is higher, not lower, in January as well. Overall, the seasonal patterns in the cash flows to equity fund families are similar to the seasonal patterns in the cash flows to individual funds, after controlling for stock market performance.

The author also ran the regression on the value weighted average cash flows to the U.S. domestic equity fund industry to examine whether the seasonal patterns are present not only on the individual fund or fund family 
level but also on the fund industry level. The unreported table shows that the seasonal patterns in the cash flows to equity mutual funds are present on the fund industry level and these patterns are not driven by specific individual funds, or fund families.

\section{THE TURN-OF-THE-YEAR EFFECT AND THE TURN-OF-THE-QUARTER EFFECT IN MUTUAL FUND FLOWS}

From the regression results in the previous section, the author finds that the net cash flows to equity funds are the highest in January and the lowest in December after controlling the stock market performance. The turn-ofthe-year period seems to be the time for mutual fund investors to review their holdings and move money into and out of equity funds. Given that December is the end of the fiscal year of most firms and the tax year of individual investors, the turn-of-the-year period would be an appropriate time for investors to review their holdings. The turnof-the-quarter period would also be the time to review holdings and make asset allocation decisions, because mutual funds must report their past performance up to the latest calendar quarter end. That is, investors would be more active in rebalancing asset allocation at the turn of the year and the turn of the quarter than the rest of the year.

In this section, the author statistically tested whether the turn-of-the-year and the turn-of-the-quarter effects exist in cash flows to equity mutual funds. In Table 4, the author provides the results from the year fixed effects regression with four indicator variables (Beginning of the year, End of the year, Beginning of the quarter, and End of the quarter) and the S\&P500 return over the month $t$ and $t-1\left(\mathrm{~S} \& \mathrm{P} 500_{\mathrm{t}}\right.$ and $\left.\mathrm{S} \& \mathrm{P} 500_{\mathrm{t}-1}\right)$. Since the seasonal patterns in cash flows to mutual funds are evident for the equity fund industry, the author ran this regression on the value weighted monthly average cash flows to mutual funds.

The most intriguing finding in Table 4 is that there is no statistically significant seasonal variation in net cash flows to equity funds other than the turn-of-the-year period. The beginning of the year is the only time of the year with significantly positive net flows, and the end of the year is the only period with significantly negative net flows. In addition, the coefficients of the beginning of the year variables are significantly positive in all models when the author used different cash flow measures as the dependent variable. It is noted that both inflow and outflow are significantly higher in January than the other time of the year. In fact, the outflow is higher, not lower, in January. One of the possible reasons for the high outflow in January could be investors moving from one fund to another. That is, mutual fund investors rebalance their portfolios in January more actively than they do during the rest of the year.

In December, the inflow to the equity funds is not statistically significantly different from other months, but the outflow increases significantly at the five percent level. The low net flows in December indicate that current investors tend to sell their shares more in December. Across all the fund flow variables, the coefficients of the beginning of the quarter and the end of the quarter are not significantly different from the other months of the year. Thus, the unique seasonal pattern in cash flows to equity mutual funds is limited to the turn-of-the-year effect, and in general, there is no turn-of-the-quarter effect. 
Table 4: The Turn of the Year Effect and the Turn of the Quarter Effect in Mutual Fund Flows

\begin{tabular}{lccc}
\hline & Inflows & Outflows & Net flows \\
\hline Intercept & $2.015^{* * *}$ & $1.949 * * *$ & 0.066 \\
& $(11.63)$ & $(11.90)$ & $(0.57)$ \\
\hline Beginning of the year & $0.880^{* * *}$ & $0.423 * *$ & $\left(2.577^{* * *}\right.$ \\
& $(5.08)$ & $0.369^{* *}$ & $(3.99)$ \\
\hline End of the year & 1.076 & $(2.29)$ & -0.193 \\
& $(1.03)$ & 0.060 & $(-1.71)$ \\
\hline Beginning of the quarter & 0.053 & $(0.54)$ & -0.007 \\
& $(0.45)$ & 0.115 & $(-0.09)$ \\
\hline End of the quarter & 0.075 & $(1.06)$ & -0.040 \\
& $(0.66)$ & 0.045 & $(-0.52)$ \\
\hline S\&P500 & 0.065 & $(1.04)$ & 0.019 \\
& $(1.40)$ & -0.019 & $(0.63)$ \\
\hline S\&P500 & 0.022 & $(-0.43)$ & 0.041 \\
& $(0.48)$ & Yes & $(1.35)$ \\
\hline Year fixed effect & Yes & 168 & Yes \\
\hline $\mathbf{R}^{2}$ & 168 & 0.541 & 168 \\
\hline Note: & 0.625 & 0.540 \\
\hline
\end{tabular}

Note: $* * *, * *$, and $*$ denote the significance level at $1 \%, 5 \%$, and $10 \%$, respectively

\section{SUMMARY AND CONCLUDING REMARKS}

In this paper, the author studied the seasonality in the cash flows of the U.S. domestic mutual funds and documents a number of intriguing findings. The author report that January is the month when equity funds experience the largest net cash flows and December is the month with the smallest net cash flows. The large net flows in January are attributed to increased purchases, and the small net flows in December are due to increased redemptions. This paper contributes to our understanding of mutual fund investors' trading behavior. The author finds that investors make asset allocation decisions more actively around the turn-of-the-year.

\section{AUTHOR INFORMATION}

Hyung-Suk Choi, Ph.D. in Finance, Assistant Professor of Ewha School of Business at Ewha Womans University in Korea.

\section{REFERENCES}

Abel, A.; Eberly, J.; Panageas, S. 2007. Optimal inattention to the stock market, American Economic Review 97, 244-249.

Agrawal, A.; Kishore T. 1994. Anomalies or illusions? Evidence from stock markets in eighteen countries, Journal of International Money and Finance 13, 83-106.

Ariel, R. 1987. A monthly effect in stock returns, Journal of Financial Economics 18, 161-174.

Barber, B. M.; Odean, T.; Zheng, L. 2005. Out of sight, out of mind, the effects of expense on mutual fund flows, Journal of Business 78, 2095-2119.

Bergstresser, D.; Poterba, J. 2002. Do after tax returns affect mutual fund inflows? Journal of Financial Economics $63,381-414$.

Bouman, S.; Jacobsen, B. 2002. The Halloween indicator, "Sell in May and Go Away": another puzzle, American Economic Review 92, 1618-1635.

Branch, B. 1977. A tax loss trading rule, Journal of Business 50, 198-207.

Carhart, M. M. 1997. On persistence in mutual fund performance, Journal of Finance 52, 57-82.

Carhart, M. M.; Kaniel, R.; Musto, D. K.; Reed, A. V. 2002. Leaning for the tape: evidence of gaming behavior in equity mutual funds, Journal of Finance 57, 661-693.

Cassidy, D. 2002. Trading on volume. New York: McGraw-Hill

Chakravarty, S. 2001. Stealth-trading: which traders' trades move stock prices? Journal of Financial Economics 61, 289-307. 
Chen, J.; Hong, H.; Huang, M.; Kubik, J. D. 2004. Does fund size erode mutual fund performance? The role of liquidity and organization, American Economic Review 94, 1276-1302.

Chevalier, J.; Ellison, G. 1997. Risk taking by mutual funds as a response to incentives, Journal of Political Economy 105, 1167-1200.

Dyl, E. A. 1977. Capital gains taxation and the year-end stock market behavior, Journal of Finance 32, 165-175.

Edelen, R.; Warner, J. 2001. Aggregate price effects of institutional trading: a study of mutual fund flow and market returns, Journal of Financial Economics 59, 195-220.

Elton, E. J.; Gruber, M. J.; Blake, C. R. 2001. A first look at the accuracy of the CRSP mutual fund database and a comparison of the CRSP and Morningstar mutual fund databases, Journal of Finance 56, 2415-2430.

Fama, E. F.; French, K. R. 1993. Common risk factors in the returns on stocks and bonds, Journal of Financial Economics 33, 3-56.

Fant, L. F. 1999. Investment behavior of mutual fund shareholders: the evidence from aggregate fund flows, Journal of Financial Markets 2, 391-402.

Frazzini, A.; Lamont, O. A. 2008. Dumb money: mutual fund flows and the cross-section of stock returns, Journal of Financial Economics 88, 299-322.

French, K. R. 1980. Stock returns and the weekend effect, Journal of Financial Economics 8, 55-69.

Gruber, M. J. 1996. Another puzzle: the growth in actively managed mutual funds, Journal of Finance 51, 783-810.

Haugen, R. A.; Lakonishok, J. 1988. The incredible January effect: the stock market's unsolved mystery, Homewood: Dow Jones-Irwin.

Hendricks, D.; Patel, J.; Zeckhauser, R. 1993. Hot hands in mutual funds: the persistence of performance, 1974-88, Journal of Finance 48, 93-130.

Hirshleifer, D.; Shumway, T. 2003. Good day sunshine: stock returns and the weather, Journal of Finance 58, 10091032.

Hong, H.; Yu, J. 2009. Gone fishin': seasonality in trading activity and asset prices, Journal of Financial Markets $12,672-702$.

Indro, D. C. 2004. Does mutual fund flow reflect investor sentiment? Journal of Behavioral Finance 5, 105-115.

Ippolito, R. A. 1992. Consumer reaction to measures of poor quality: evidence from the mutual fund industry, Journal of Law and Economics 35, 45-70.

Jagannathan, R.; Wang, Y. 2007. Lazy investors, discretionary consumption, and the cross-section of stock returns, Journal of Finance 62, 1623-1661.

Johnson, W. T.; Poterba, J. M. 2010. The effect of taxes on shareholder inflows around mutual fund distribution dates, Unpublished Working Paper.

Kamstra, M. J.; Kramer, L. A.; Levi, M. D.; Wermers, R. 2010. Seasonal asset allocation: evidence from mutual fund flows, Unpublished Working Paper.

Keim, D. 1983. Size related anomalies and the stock return seasonality: further empirical evidence, Journal of Financial Economics 28, 67-83.

Khorana, A.; Servaes, H. 1999. The determinants of mutual fund starts, Review of Financial Studies 12, 1043-1074.

Lakonishok, J.; Maberly, E. 1990. The weekend effect: trading patterns of individual and institutional investors, Journal of Finance 45, 231-243.

Lakonishok, J.; Smidt, S. 1988. Are seasonal anomalies real? a ninety-year perspective, Review of Financial Studies $1,403-425$.

Miron, J.; Beaulieu, J. 1996. What have macroeconomists learned about business cycles from the study of seasonal cycles?, Review of Economics and Statistics 78, 54-66.

Musto, D. K. 1997. Portfolio disclosures and year-end price shifts, Journal of Finance 52, 1653-1688.

Ng, L.; Wang, Q. 2004. Institutional trading and the turn-of-the-year effect, Journal of Financial Economics 74, 343-366.

Reinganum, M. R. 1983. The anomalous stock market behavior of small firms in January: empirical tests for tax-loss selling effects, Journal of Financial Economics 12, 89-104.

Ritter, J. R. 1988. The buying and selling behavior of individual investors at the turn of the year, Journal of Finance 43, 701-717.

Ritter, J. R.; Chopra, N. 1989. Portfolio rebalancing and the turn-of-the-year effect, Journal of Finance 44, 149-166.

Roll, R. 1983. Vas ist das? The turn-of-the-year effect and the return premia of small firms, Journal of Portfolio Management 9, 18-28. 
Rozeff, M. S.; Kinney, Jr. W. R. 1976. Capital market seasonality: the case of stock returns, Journal of Financial Economics 3, 379-402.

Sapp, T.; Tiwari. A. 2004. Does stock return momentum explain the smart money effect? Journal of Finance 59, 2605-2622.

Sirri, E. R.; Tufano, P. 1998. Costly search and mutual fund flows, Journal of Finance 53, 1589-1622.

Spitz, A. E. 1970. Mutual fund performance and cash inflows, Applied Economics 2, 141-145.

Warther, V. A. 1995. Aggregate mutual fund flows and securities returns, Journal of Financial Economics 39, 209 235.

Zheng, L. 1999. Is money smart? A study of mutual fund investors' fund selection ability, Journal of Finance 54, 901-933. 


\section{NOTES}

